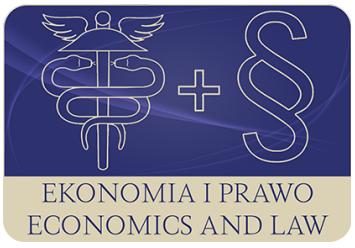

EKONOMIA I PRAWO. ECONOMICS AND LAW

Volume 16, Issue 1, March 2017

p-ISSN 1898-2255, e-ISSN 2392-1625

www.economicsandlaw.pl

ORIGINAL ARTICLE

received 30.09.2015; revised 15.07.2016; accepted 31.03.2017

Citation: Gorączkowska, J. (2017). Technical advancement and the stimulation of companies innovation activity by business support organisations in developed regions. Ekonomia i Prawo.

Ecomomics and Law, 16(1): 21-33. doi:10.12775/EiP.2017.002.

\title{
Technical advancement and the stimulation of companies innovation activity by business support organisations in developed regions
}

\author{
JADWIGA GORĄCZKOWSKA \\ University of Zielona Góra, Faculty of Economics and Management, Division of Innovation \\ and Entrepreneurship, ul. Podgórna 50, 65-001 Zielona Góra, Poland \\ $\nabla$ j.goraczkowska@wez.uz.zgora.pl
}

\begin{abstract}
Motivation: Currently, an increasing role in achieving the competitive advantage is attributed to knowledge and its conversion to new products and services. For this reason, institutions have been set up, which are designed to stimulate the innovation activity in the economy. Their development was initiated in developed countries, and then moved to the developing countries.

Aim: The article presented the influence of business support institution, which most frequently occur in the Polish reality, i.e., technological parks, technological incubators, academic business incubators, technology transfer centers, business angel networks, local or regional loan funds, credit guarantee funds and training-advisory centers for the innovation activity of industrial companies with consideration of the manufacturing techniques

used by them in the developed regions of Poland, i.e., from the Lower Silesia, Silesia and Greater Poland.

Results: Innovation attributes were distinguished according to the standards of studying the innovation activity contained in the Oslo methodology. For the conduct of analyses the probit modeling was used. The hypothesis of the article is the statement that the innovation of companies will grow after establishing cooperation with business support institutions, while its level will be bigger when the level of manufacturing technique used

by the companies is bigger.
\end{abstract}


Keywords: innovation; business support organizations; industry JEL: O31; O32

\section{Introduction}

Along with the accelerating technological development grows the role of innovation in the modern world. Its implementation, especially from the point of view of companies in catching-up countries, like Poland, is not an easy task. Implementation of innovative solutions ends in success, when the right conditions are met. The proper diagnosis and the use of the innovation potential depends on the state of knowledge on the research and developmental sphere, properly constructed institutional framework for the innovation development and the use of the market potential (Bundesministerium für Ernährung, Landwirtschaft und Verbraucherschutz, 2012). Over the years, the market has changed to a large extent. Especially in the last 20 years we can notice the loss of importance of traditional factors of the competitive advantage (labour, land, capital) in favour of the advancing globalization processes and the computer and telecommunications revolution (Audretsch, 1998, p. 19). The growing role in achieving the competitive advantage is attributed to knowledge and its conversion to new products and services.

For this reason, there were initiated programs, which aim to stimulate the innovation activity. This was evident in the change of a paradigm of the business entities support. It has been moved from the market established companies or those, which are in a difficult situation and require intervention for new, innovation companies and types of the business activity. The pro-development factors were activated, such as creativity, innovation and entrepreneurship (Audretsch, 1998, p.12). These activities should be carried out within the framework, socalled triple helix, so within the cooperation between companies, the sphere of science and the sphere of government. As the international research shows, in such systems occurs the significant improvement of the competitive position of companies and regions (Etzkowitz, 2002, pp. 2-5).

In accordance with Oslo methodology an innovation is the implementation of a new or significantly improved product (good or service), or process, a new marketing method, or a new organizational method in business practices, workplace organization or external relations (OECD \& Eurostat, 2005, p. 46). The minimum requirement for a change in a firm's products or functions to be considered an innovation is that it is new (or significantly improved) to the firm (OECD \& Eurostat, 2005, p. 17). Support of the innovation implementation can be defined as all actions and instruments, which facilitate the conduct of the innovation process in the enterprises (Klodt, 2013). They are undertaken not only within the innovation policy or entrepreneurship, but also regional, industrial, agricultural, educational and any other, which contains elements playing an important role in the process of developing innovation and entrepreneurship. As a result of carrying out these policies, focused on innovation, regional author- 
ities stimulate the formation of institutions, which are to contribute to the increase of the innovation level of companies. Business support organizations are in fact the executive link of the support programs (Matusiak et al., 2011, p. 35). Because of them the potential of innovation systems is strengthened (European Commision, 2012, p. 35). Currently in Poland the group of the most frequent business support institutions belong: technological parks, technological incubators, academic entrepreneurship incubators, technology transfer centers, business angel networks, local and regional loan funds, loan guarantee funds and training-advisory centers.

These institutions were moved to the Polish land from the developed countries. Therefore, it is interesting how they will affect the innovation activity in the catching-up country, like Poland. Will their effectiveness be significant? If one takes into account different levels of technical advancement of companies, will the differences in their impact be visible? The aim of the article, thus, is to examine what is the effectiveness of the influence of the business support institutions on the innovation activity of industrial companies using the low, average-low, average-high and high manufacturing technique. The basic research hypothesis of the paper is the statement that the business support institutions will increase the chances to implement new solutions. Moreover, with the increase of the technique used by the companies, the probability of occurrence of innovation activity should grow.

\section{Methodology of the conducted study}

The study of the influence of the business support institution on the innovation activity was conducted in 2013 and included a time range of three full years of the company's functioning, so the years of 2010-2012 . For analyses were selected companies from three developed provinces in Poland, i.e., Lower Silesia, Silesia and Greater Poland. The high level of development of these regions was determined based on expenditures on the innovation activity provided by regional Statistical Offices. Their sizes are presented in table 1.

Analyses were conducted on 522 companies using the average-high and high manufacturing technique in the production ${ }^{2}, 729$ entities using the average-low and 1201 companies from the sector of low technology.

The studied areas of the innovation activity were selected in accordance with the international standards consistent with the Oslo methodology. These were:

- expenditure on the innovation activity combined with their structure, i.e., expenditure on the research-developmental activity, investment in new fixed assets and new computer software (OECD \& Eurostat, 2005, pp. 92-93);

\footnotetext{
${ }^{1}$ Information on innovation activity include three full years of enterprises operation.
}

${ }^{2}$ Companies using average-high and high technology have been combined, because the number of entities from the sector of high technology was over 100, what significantly hampers the estimation of statistical models (too small sample size). 
- implementation of new products and technological processes (including new manufacturing methods, by-production systems and support systems) (OECD \& Eurostat, 2005, pp. 48-49).

In the study, using the probit modelling, it was checked how the above innovation activity attributes affect the business support institutions in the companies using the low, average-low, average-high and high manufacturing technology. The division of the industry in terms of manufacturing technique is based on the qualifications accepted by OECD countries in 1997 (Hatzichronoglou, 1997, pp. 1-26). It has been referred to the Polish Qualification of Activities (PKD 2007), where low technology sector included manufacture of food products, beverages, tobacco products, textiles, wearing apparel, leather and related product, wood and of products of wood and cork, furniture, articles of straw and plaiting materials, paper and paper products and printing and reproduction of recorded media. Medium-low-technology sector included manufacture of coke and refined petroleum products, rubber and plastic products, other non-metallic mineral products, basic metals, fabricated metal products, except machinery and equipment. Medium-high-technology sector included manufacture of chemicals and chemical products, electrical equipment, machinery and equipment n.e.c., motor vehicles, trailers and semi-trailers and other transport equipment. High-technology sector included manufacture of basic pharmaceutical products and pharmaceutical preparations, computer, electronic and optical products, air and spacecraft and related machinery, medical and dental instruments and supplies.

Probit modelling is based on the theory of probability. The selection of this method was dictated by the dichotomous nature of the variables adopted for testing - respondents' answers were attributed with the 0 values in case of the negative answer to the questions (e.g. when the company did not incur expenditure for the $\mathrm{R}+\mathrm{D}$ activity) and $\mathrm{l}$ in case of the positive answer (e.g. when the expenditure were incurred). In case of the model, when the dependant variable achieves the value of 0 or 1 , the expected value of the variable can be interpreted as the conditional probability of implementing the given event with the set values of the independent variable (Świadek, 2011, p. 102).

The analysis and interpretation of results takes place similarly to the classical method of regression. The ways of selecting the model and testing hypotheses have a similar scheme. The most important differences, which occur, are brought to the fact that calculations are more complicated and time-consuming, and the calculation of the values and making graphs of residues often does not bring anything new to the model (Stanisz, 2007, p. 217). Therefore, the parameter values of the model are not interpreted. While significant is the sign by the directional coefficient of the model. If it is positive, it means that the probability of occurrence of the studied innovation phenomenon (e.g. introduction of a new product) in the group of companies using the services of the given support institution (e.g. technological incubator) is greater than in the group 
of entities, which do not cooperate with this institution. In case when the coefficient is negative, this dependency is reversed.

The models were estimated using the Statistica program. In addition to the models, in the empirical part, there will also be presented the values of probability of occurrence of particular innovation phenomena in the group of companies cooperating with the given support institution and in the opposite group, i.e., the group of not cooperating companies. The statistical significance of the models was assessed based on the chi-square statistics, and the directional parameter $t$-Student. In the model estimation the ranges of trust were adopted at the level of 0.95 .

\section{The impact of the business support organisations on the innovation of industrial companies - results of the analysis}

Analysing the impact of technological parks on the innovation activity of industrial companies it can be noticed that they impacted on it systemically. This was revealed by the positive impact of these institutions on all analysed innovation attributes. Taking into account the probability values of occurrence of particular phenomena (attributes) in the group of entities, which used the park services, it was observed that apart from investments in new fixed assets and software, it grew with the growth of the level of the manufacturing technology used by the companies. In all analysed areas, except for investments in software and new by-product systems, this growth was also noted in the opposite group of entities, i.e. enterprises, which did not cooperate with parks.

In the studied areas, parks increased the probability of the occurrence of innovation in a variety of ways. In the case of implementation of new manufacturing processes in companies from the sectors of low technology of manufacturing, the probability of their implementation among the entities cooperating with parks was 1.31-times greater than in the opposite group, in entities of average-low technology 1.39-times, and average-high and high 1.25-times. In the case of investment in new fixed assets, computer software and expenditures on the research-developmental activity, differences in the multiple probabilities decreased with the increase of the technology level. It should be emphasized that parks were characterized by a very high efficacy in the case of stimulation of $\mathrm{R}+\mathrm{D}$ activities, where one could notice over 2.5-times increase of chances of their implementation after establishing cooperation with parks in entities from the low technology sector, 1.9-times in entities using the average-low technology and 1.63-times the average-high and high.

Centers of technology transfer were characterized by a slightly smaller efficiency than parks. Centers, like the technological parks, significantly increased the chance to incur expenditures for the $\mathrm{R}+\mathrm{D}$ activity. Moreover, centers increased the probability to implement new fixed assets (with special 
consideration of new machines and devices) and new by-production systems in the entities using the low and average-low manufacturing technology. The chances for the implementation of new software and new products grew after establishing cooperation with centers in companies using the average-low, average-high and high technology. Moreover, centers contributed to the implementation of new processes in low technology and new manufacturing methods and support systems in the entities of average-low technology.

Technological incubators were characterized by the highest efficiency in the case of companies using the average-high and high technology (seven models statistically significant), slightly smaller in the case of low technology (six models), and the smallest average-low (four models). Once again the principle was repeated, which occurred in the case of previous institutions, i.e. with the growth of the level of the used technology decreased the difference of multiple probabilities between entities using the services of incubators, and companies which did not do that, with the simultaneous increase (or the same) value of probabilities. Incubators increased the chances to increase the machine park of companies in all studied companies. In the sectors of low and average-high and high technology in terms of incubators occurred the growth of probability of the occurrence of expenditures on the $\mathrm{R}+\mathrm{D}$, investment in new fixed assets and new manufacturing methods. In entities of low and average-low technologies grew the chances to implement new manufacturing processes, with emphasis on new by-production systems. The common element of companies from the sectors of average-low and average-high and high technology were investments in computer software. Moreover, in the entities of average-high and high technology, thanks to using the incubator services, increased the chances for investments in new buildings, premises and lands and the processes supporting the operation of companies (table 2).

Academic entrepreneurship incubators were characterized by a much lesser effectiveness than other studied innovation centers. For areas, in which the impact of academic incubators was joint for several types of technology, with the increase of the used level of technology, noticeable was not only the decrease of multiple differences of probability but also the decrease of values of probabilities in the group of companies cooperating with incubators. In the opposite group with the increase of technology these chances grew. However, it is important that after establishing cooperation with the academic incubator they were greater than in the group of entities, which did not do this.

Activity of the business angel network in the studied regions was noted only in companies from the sector of average-high and high technology. Their impact was very large, as there were estimated eight models meeting the conditions of the statistical significance at ten possible. Therefore, it can be assumed that in these sectors their impact was systemic. However, interesting is the fact that the lack of models concerns the increase of chances for the implementation of new manufacturing methods and implementation of new products into the market. 
Training and consulting centers, just like technological parks, impacted systemically on the stimulation of innovation activity. In the group of companies cooperating with the centers, with the increase of the level of the used technology also grew the probability of occurrence of particular innovation phenomena. In the opposite group the situation did not always take place. Centers increased the chances for the implementation of new technological processes in companies from all studied levels of technology (the lack of influence was noted in new manufacturing methods in the case of average-high and high technology). Training centers increased the probability of occurrence of investments in new fixed assets (total). In all entities, as a result of using the services of the centers, grew the chances for the implementation of the new computer software and conduct of the research-developmental activity (table 3).

Local and regional loan funds impacted only on the stimulation of the innovation activity in companies from the sector of low technology in three areas. This concerned the investment in new fixed assets (total) and new technological processes, while in the majority they referred to the new by-production systems.

Activity of the credit guarantee funds was slightly higher than the loan funds. It should be emphasizes that for the first time in the analyses appeared the negative directional coefficient. It concerned the expenditure on the $\mathrm{R}+\mathrm{D}$ activity in companies using the average-low manufacturing technology. This means that the chances for the occurrence of this investment in the group of entities using the services of funds were smaller than in the group of companies not cooperating with them. Moreover, in all studied companies the guarantee funds contributed to the increase of chances for the implementation of new technological processes, in particular the by-production systems. While in the companies using the low and average-high technology grew the probability for investments in new fixed assets (table 4).

\section{Conclusion}

Comparative analysis of the impact of the business support institution on the innovation activity of industrial companies taking into account the manufacturing technology used by them provided some interesting information. We can assume that after establishing cooperation with the support institutions, with the increase of the level of the applied technology also increases their effectiveness. This means that the higher level of development allows the better use of the institution's potential. It is also important that in the entities, which did not use the services of centers also grew the chances for the occurrence of the innovation activity. The only significant exceptions from this rule (i.e. where differences in values of probabilities were high) occurred in the case of investment in fixed assets and software after establishing cooperation with technological parks. Therefore, the argument can be drawn that in the entities using the average-high and high technology more significant is the intellectual property than 
the production itself (which requires large rooms). The decrease of the probability values is noticeable in the case of cooperation with the academic entrepreneurship incubators. Activity of this institution is thus significant for companies using the low manufacturing technology.

Technological parks and training-advisory centers have a systemic impact on the stimulation of innovation activity in the regions developed in the industry. They constitute an important link in the chain contributing to the stimulation of innovation in the studied regions. Due to the fact that for the entities cooperating with technological parks the values of probabilities are greater than in the case of cooperation with the centers, it can be assumed that they are characterized by the greater effectiveness than the centers.

In the developed regions there was also visible the important influence on the innovation in the case of centers of the technology transfer and technological incubators. This in particular applies to the increase of chances for the occurrence of the $\mathrm{R}+\mathrm{D}$ activities. The contribution in this area was also invaluable in the case of technological parks and training-advisory centers. It is a very positive phenomenon, because this way grow the chances for the implementation of own innovations, and not only copying simple solutions from abroad.

Activity of the business angel network is visible only in the case of entities using the average-high and high technology. This is not a surprising phenomenon, because the business angels are interested in the innovations and risky projects with the high technological advancement. Surprising is only the fact that the estimated models did not occur for such phenomena like the implementation of new products and manufacturing methods. This may mean that the angels were presented with the ready made products or technologies, which should be implemented to the market, so the focus was on other aspects of the innovation activity, which contributed to this process.

Activity of the regional loan funds is essential in companies from the sector of low technology. This results mainly from the low amount of loans granted by the funds (usually up to PLN 120 thousand). Highly innovative projects require greater funding, what confirms the lack of interest in these institutions by entities from the sector of the average-high or high technology. In these sectors their place was taken by the business angel networks. For this reason, loan funds should be better treated like the institutions supporting entrepreneurship rather than innovation.

Activity of credit guarantee funds is slightly larger. It is visible in enterprises from all studied areas, what means that the guaranteed loans are spent on the innovation activity regardless of the level of the applied technology. However, it is important that in the companies using the average-low technology of manufacturing appeared a model with the negative directional coefficient, what means that the guaranteed loans and credits are not spent for the $\mathrm{R}+\mathrm{D}$ activity. It can be assumed that entrepreneurs themselves first finance this activity, and at 
the time of obtaining a greater level of certainty as to its success credit the actions connected with its implementation to the market.

Given the above conclusions it can be assumed that the research hypothesis posed at the beginning of the article was partially confirmed. Once you have established cooperation with the centers, in most cases, the chances for the occurrence of the innovation activity increased with the growth of the level of the applied technology. Also the significant contribution of these institutions was confirmed (especially the innovation centers and counseling centers) into the development of innovation of the studies regions.

\section{References}

Audretsch, B. (1998). Agglomeration and the location of innovative activity. Oxford Review of Economic Policy, 14(2). doi:10.1093/oxrep/14.2.18.

Bundesministerium für Ernährung, Landwirtschaft und Verbraucherschutz. (2012). Programm zur Innovationsförderung. Retrieved 31.06.2013 from http://www.bmelv.de.

Etzkowitz, H. (2002). The Triple Helix of University - Industry - Government. Implications for Policy and Evaluation, Institutet för studier av utbildning och forskning Working Paper, 11.

European Commision. (2012). Evaluation of Innovation Activities. Guidance on methods and practices. Retrieved 31.06.2013 from http://ec.europa.eu.

Hatzichronoglou, T. (1997). Revision of the High-Technology Sector and Product Classification. OECD Science, Technology and Industry Working Papers, 02. doi:10.1787/134337307632.

Klodt, H. (2013). Innovationsförderung, Gabler Wirtschaftslexikon. Retrieved 31.06.2013 from http://wirtschaftslexikon.gabler.de.

Matusiak, K.B., Mażewska, M., \& Banisch, R. (2011). Budowa Skutecznego Otoczenia Innowacyjnego Biznesu w Polsce, cele i zatożenia Inicjatywy Polskiej Agencji Rozwoju Przedsiębiorczości. Retrieved 31.06.2013 from http:// pomorskiewunii.pomorskie.eu.

OECD \& Eurostat (2005), Oslo Manual: Guidelines for Collecting and Interpreting Innovation Data, 3rd Edition, doi:10.1787/9789264013100-en.

Stanisz, A. (2007). Przystępny kurs statystyki z zastosowaniem Statistica PL na przyktadach z medycyny. Modelowanie liniowe i nieliniowe. Kraków: StatSoft Polska.

Świadek, A. (2011). Regionalne systemy innowacji w Polsce. Warszawa: Difin.

\section{Acknowledgements}

Author contributions: author have given approval to the final version of the article.

Funding: this research was fully funded by the University of Zielona Góra. 


\section{Appendix}

Table 1.

Expenditures on innovation activities in industry in researched regions in 2012

\begin{tabular}{crr}
\hline Province & Expenditures on innovation activities (in thousand PLN) & Place in Poland \\
\hline Dolnośląskie & 3002557 & 2 \\
Śląskie & 2511620 & 3 \\
Wielkopolskie & 1989196 & 4 \\
\hline
\end{tabular}

Source: Own preparation. 


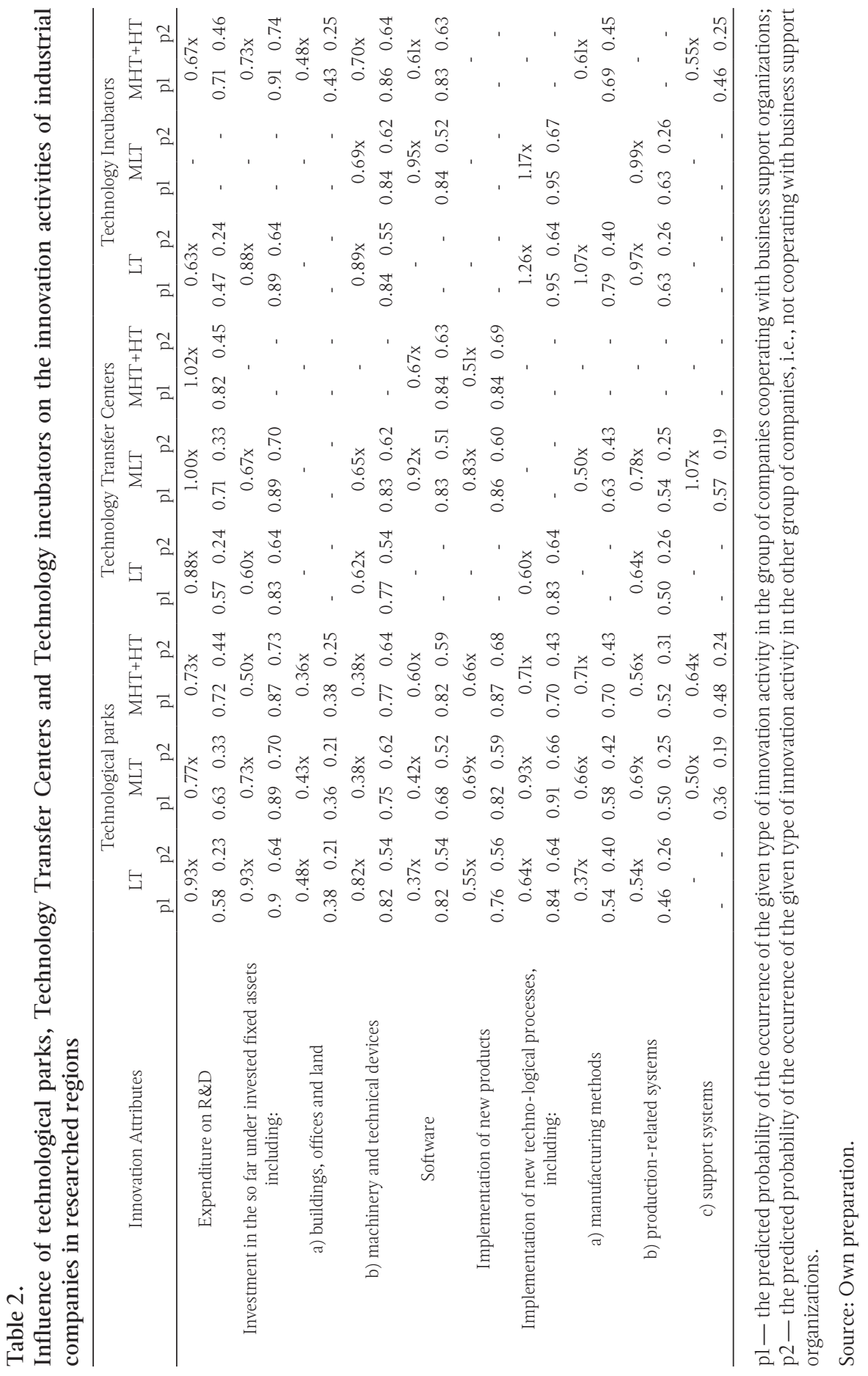




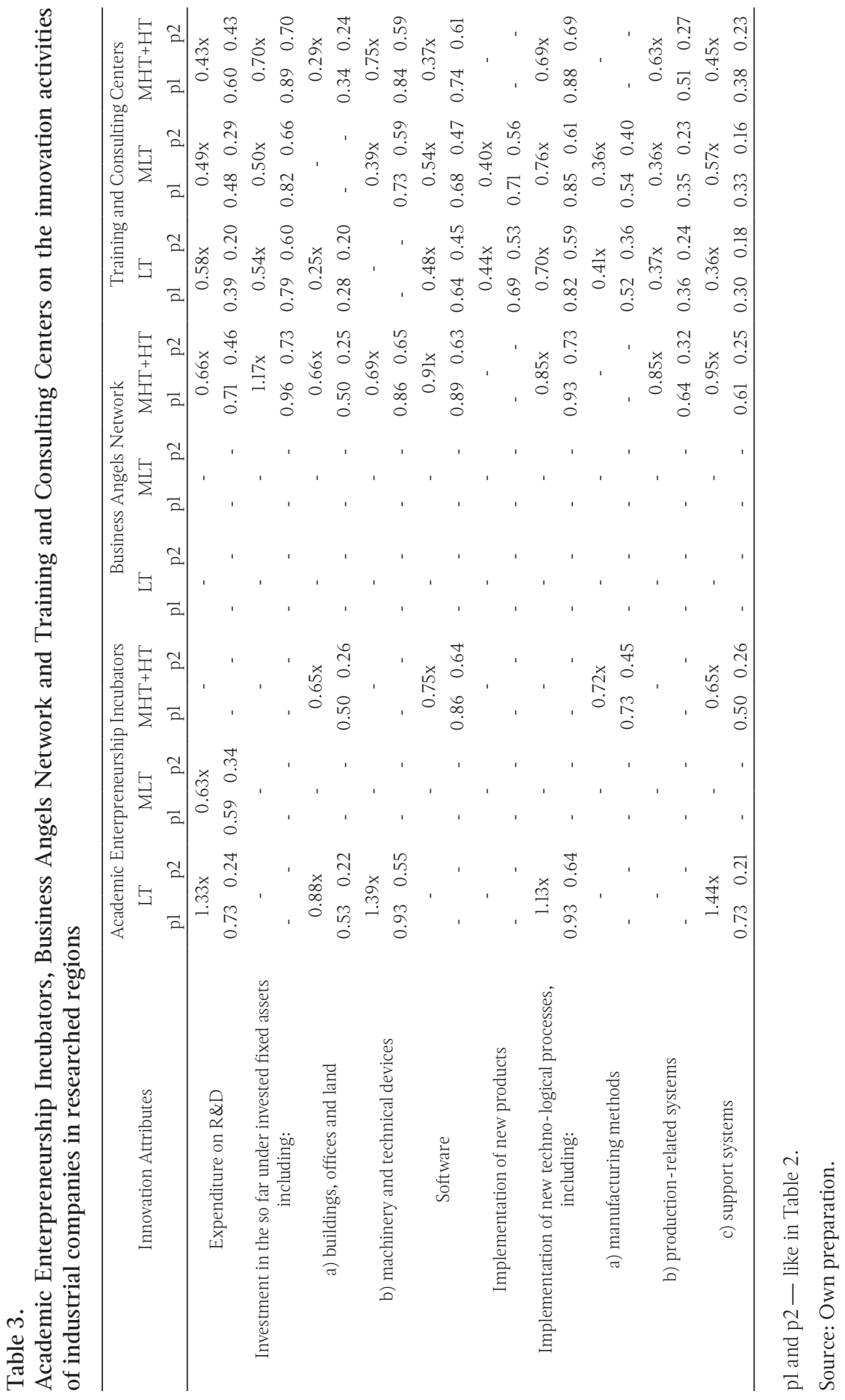


Table 4.

Influence of Local and Regional Loan Funds and Credit Guarantee Funds on the innovation activities of industrial companies in researched regions

\begin{tabular}{|c|c|c|c|c|c|c|c|c|c|c|}
\hline \multirow{3}{*}{ Innovation Attributes } & \multicolumn{6}{|c|}{ Local and Regional Loan Funds } & \multicolumn{4}{|c|}{ Credit Guarantee Funds } \\
\hline & \multicolumn{2}{|c|}{ LT } & \multicolumn{2}{|c|}{ MLT } & \multicolumn{2}{|c|}{$\mathrm{MHT}+\mathrm{HT}$} & LT & \multicolumn{2}{|c|}{ MLT } & $\mathrm{MHT}+\mathrm{HT}$ \\
\hline & pl & p2 & $\mathrm{pl}$ & p2 & $\mathrm{pl}$ & p2 & p2 & pl & p2 & p2 \\
\hline \multirow{2}{*}{ Expenditure on R\&D } & \multicolumn{2}{|c|}{-} & \multicolumn{2}{|l|}{ 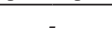 } & \multicolumn{2}{|c|}{-} & - & \multicolumn{2}{|c|}{$-0.29 x$} & - \\
\hline & - & - & - & - & - & - & - & 0.26 & 0.36 & - \\
\hline \multirow{2}{*}{$\begin{array}{l}\text { Investment in the so far under } \\
\text { invested fixed assets including: }\end{array}$} & \multicolumn{2}{|c|}{$0.28 \mathrm{x}$} & \multicolumn{2}{|c|}{-} & \multicolumn{2}{|c|}{-} & $0.40 \mathrm{x}$ & \multicolumn{2}{|c|}{-} & $0.64 \mathrm{x}$ \\
\hline & 0.73 & 0.63 & - & - & - & - & $0.77 \quad 0.63$ & - & - & 0.890 .73 \\
\hline a) buildings, offices and land & \multicolumn{2}{|c|}{-} & & & - & \multicolumn{2}{|c|}{-} & - \\
\hline \multirow{2}{*}{$\begin{array}{l}\text { b) machinery and technical } \\
\text { devices }\end{array}$} & \multicolumn{2}{|c|}{-} & \multicolumn{2}{|c|}{-} & \multicolumn{2}{|c|}{-} & $0.45 x$ & \multicolumn{2}{|c|}{-} & - \\
\hline & - & - & - & - & - & - & $0.70 \quad 0.52$ & - & - & - \\
\hline Software & & . & & & & & - & & & - \\
\hline $\begin{array}{l}\text { Implementation of new } \\
\text { products }\end{array}$ & & & & & & & - & & & - \\
\hline Implementation of new tech- & & $7 x$ & & & & & $0.57 x$ & 0. & lx & $0.90 x$ \\
\hline nological processes, including: & 0.75 & 0.62 & - & - & - & - & $0.81 \quad 0.62$ & 0.80 & 0.66 & $0.93 \quad 0.72$ \\
\hline a) manufacturing methods & & . & & & & & - & & & - \\
\hline & & $6 x$ & & & & & $0.21 \mathrm{x}$ & 0.2 & $9 x$ & $0.36 x$ \\
\hline b) production-related systems & 0.34 & 0.25 & - & - & - & - & $0.33 \quad 0.25$ & 0.35 & 0.25 & $0.46 \quad 0.32$ \\
\hline c) support systems & & . & & & & & - & - & & - \\
\hline
\end{tabular}

pl and p2 - like in Table 2.

Source: Own preparation. 
